\title{
IMPLEMENTASI TRAVELLER GAME LEARNING UNTUK MENINGKATKAN HASIL BELAJAR DAN KETERAMPILAN SOSIAL SISWA
}

\section{IMPLEMENTATION OF TRAVELLER GAME LEARNING TO IMPROVE STUDENT LEARNING OUTCOMES AND SOCIAL SKILLS}

\author{
EKO PRASETYO UTOMO
}

SMP Negeri Model Terpadu Bojonegoro

\begin{abstract}
Received: March 09, 2021

This study aimed to: 1) the implementation of Traveler Game Learning assisted by the media Jelajah Nusantara; 2) improving students' cognitive learning outcomes; and 3) improving 'tudents' social skills. This research method uses Classroom Action Research (CAR). The results of this study indicate an increase in three aspects, namely aspects of the quality of learning by teachers, aspects of student cognitive learning outcomes and aspects of social skills. The quality of learning by teachers increased from $85.71 \%$ in the cycle I to $91.42 \%$ in cycle II. Mastery of students' cognitive learning outcomes classically increased from $76.67 \%$ in cycle I to $90 \%$ in cycle II. The quality of students' social skills increased from $79.05 \%$ in cycle I to $90 \%$ in cycle II. Based on these conclusions, the use of traveler learning games can be used as an alternative in social studies learning for the junior high school level
\end{abstract}

\begin{abstract}
Abstrak. Tujuan penelitian ini yaitu untuk mengetahui: 1) implementasi Traveller Game Learning berbantuan media Jelajah Nusantara; 2) peningkatkan hasil belajar kognitif siswa; dan 3) peningkatkan keterampilan sosial siswa. Metode penelitian ini menggunakan Penelitian Tindakan Kelas (PTK). Subjek penelitian yaitu kelas VIII A sejumlah 30 siswa. Tempat penelitian di SMP Negeri Model Terpadu Bojonegoro. Waktu penelitian bulan Agustus-September 2019. Teknik pengumpulan data yaitu observasi dan tes. Pada hasil penelitian menunjukkan terjadi peningkatan di tiga aspek yaitu aspek kualitas pembelajaran oleh guru, aspek hasil belajar kognitif siswa dan aspek keterampilan sosial. Adanya peningkatan ini melalui dua siklus yang sudah dilakukan. Kualitas pembelajaran oleh guru semula $85,71 \%$ siklus I meningkat menjadi 91,42\% pada siklus II dengan kategori sangat baik. Ketuntasan hasil belajar kognitif siswa secara klasikal meningkat dari $76,67 \%$ pada siklus I kategori baik menjadi $90 \%$ pada siklus II kategori sangat baik. Kualitas keterampilan sosial siswa dari 79,05\% kategori baik meningkat menjadi 90\% pada siklus II dengan kategori sangat baik. Berdasarkan kesimpulan berikut, penggunaan game traveller learning bisa digunakan sebagai alternatif dalam pembelajaran IPS untuk jenjang SMP
\end{abstract}

Keywords: $\quad$ Traveller Game Learning, Jelajah Nusantara, Learning Outcomes, Social Skills

Kata kunci: $\quad$ Traveller Game Learning, Jelajah Nusantara, Hasil Belajar, Keterampilan Sosial

$\left(^{\star}\right)$ Corresponding Author:

How to Cite: Utomo, E.P., (2021). Implementasi Traveller Game Learning Untuk Meningkatkan Hasil Belajar Dan Keterampilan Sosial Siswa. Jurnal Lingkar Mutu Pendidikan, 18 (2), 153-159. https://doi.org/10.54124/ilmp.v18i1.26

\section{PENDAHULUAN}

Upaya meningkatkan semangat kebangsaan, patriotisme dan pemahaman akan bangsa di kalangan pelajar dalam mata pelajaran IPS salah satunya dengan penguatan materi interaksi keruangan pada kehidupan di antara negara-negara ASEAN. Indonesia sebagai bagian dari organisasi ASEAN memiliki posisi yang strategis bila ditinjau dari wilayah dan letaknya. Berada diantara dua benua yaitu Australia dan Asia dan dua samudera yaitu Hindia dan Pasifik sejak dulu negara Indonesia sudah menjadi daya tarik bagi negara-negara Eropa dan interaksi dengan negara-negara sekitar.

Berdasarkan analisis ketuntasan hasil belajar kognitif siswa kelas VIII A dalam materi interaksi keruangan kehidupan di negara-negara ASEAN menunjukkan bahwa dari jumlah siswa sebanyak 30, 
yang dinyatakan tuntas 17 siswa dan sisanya 13 siswa dinyatakan tidak tuntas. Hal tersebut dapat diartikan bahwa tingkat ketuntasan siswa hanya 56,67\% dari ketuntasan klasikal 80\%.

Selain ditinjau dari tingkat ketuntasan, jika dianalisis tentang nilai rata-rata kelas hasil tes materi tersebut menunjukkan bahwa nilai rata-rata kelas 68,58. Untuk nilai Kriteria Ketuntasan Minimal (KKM) bidang studi IPS kelas VIII yaitu 75. Kondisi tersebut menunjukkan bahwa hasil tes penilaian masih di bawah KKM.

Berdasarkan hasil observasi pembelajaran IPS pada materi yang sama menunjukkan bahwa keterampilan sosial siswa kelas VIII A dalam kegiatan diskusi kelompok masih rendah terutama pada kegiatan berbagi tugas dan tanggung jawab. Pada kegiatan ini beberapa siswa dalam kelompok masih bergantung pada siswa yang lain dalam mengerjakan tugas. Selain itu pada kegiatan kerja sama juga rendah yaitu dalam menyelesaikan tugas kelompok hanya beberapa siswa yang mendominasi dalam pengerjaan tugas.

Berangkat dari kondisi rendahnya hasil belajar kognitif serta keterampilan sosial siswa pada materi interaksi keruangan kehidupan di negara-negara ASEAN maka seorang guru mata pelajaran IPS perlu mendesain pembelajaran dengan model pembelajaran yang tepat. Salah satu yang dapat digunakan adalah inovasi pembelajaran dalam bentuk kombinasi model dan media pembelajaran. Model pembelajaran diartikan sebagai pola dalam merancang pembelajaran atau sintak pembelajaran di kelas sekaligus perangkatnya dalam upaya mencapai tujuan pembelajaran tertentu (Akbar, 2013).

Berdasarkan uraian di atas maka tujuan penelitian ini untuk mengetahui: 1) implementasi Traveller Game Learning berbantuan media Jelajah Nusantara pada mata pelajaran IPS di kelas VIIIA SMP Negeri Model terpadu Bojonegoro; 2) peningkatkan hasil belajar kognitif siswa; dan 3) peningkatkan keterampilan sosial siswa.

Traveller Game Learning merupakan suatu model pembelajaran yang dikembangkan dari teori belajar konstruktivisme dan Vygotsky. Konstruktivisme dalam pembelajaran memberikan siswa kesempatan untuk mengkonstruksi sendiri pengetahuan yang mereka peroleh (Suparno, 2014). Teori belajar Vygotsky memberikan kesempatan kepada siswa bekerja sama dalam kelompok dengan memberdayakan teman yang lebih terampil membantu teman lainnya (Schunk, 2012).

Untuk melengkapi implementasi Traveller Game Learning maka digunakan sebuah media dengan nama Jelajah Nusantara. Media ini adalah media visual yang berisi peta wilayah dan informasi pendukung tentang mata pelajaran IPS materi interaksi keruangan dalam kehidupan di negaranegara ASEAN. Media ini secara spesifik membantu siswa mengenal negara-negara tersebut, pola interaksinya, dan pengaruh perubahan serta interaksi keruangan terhadap kehidupan negara ASEAN yang mereka dapatkan dalam kegiatan pembelajaran IPS. Perpaduan model dan media pembelajaran ini diharapkan mampu meningkatkan hasil belajar kognitif dan keterampilan sosial siswa.

\section{METODE PENELITIAN}

Penelitian ini menggunakan prosedur penelitian tindakan kelas atau Classroom Action Research (Hopkins, 2011). Dilaksanakan melalui siklus berulang yang terdiri dari empat tahap utama kegiatan, yaitu (a) perencanaan; (b) tindakan; (c) pengamatan; dan (d) refleksi. Subjek penelitian ini yaitu seluruh peserta didik kelas VIII A tahun ajaran 2019/2020 sejumlah 30 siswa. Tempat penelitian ini di SMP Negeri Model Terpadu Bojonegoro, waktu penelitian dilaksanakan tahun ajaran 2019/2020 semester ganjil pada bulan Agustus sampai dengan September 2019.

Teknik pengumpulan data dalam penelitian ini yaitu teknik observasi serta tes. Observasi dilaksanakan untuk mengumpulkan data-data keterlaksanaan model Traveller Game Learning berbantuan media Jelajah Nusantara oleh guru pada proses pembelajaran IPS di kelas. Lembar observasi ini disusun pula untuk mengumpulkan data-data pengamatan keterampilan sosial saat kegiatan pembelajaran berlangsung. Tes digunakan untuk mengetahui hasil belajar kognitif siswa sesudah implementasi model dan media ini pada materi interaksi keruangan kehidupan negaranegara ASEAN.

Instrumen yang digunakan adalah lembar pengamatan implementasi Traveller Game Learning berbantuan media Jelajah Nusantara oleh guru serta keterampilan sosial siswa dan tes belajar kognitif. Teknik analisis data tentang kemampuan guru dalam mengelola pembelajaran dan keterampilan 
sosial siswa dalam proses pembelajaran dianalisis dengan melakukan penghitungan rerata tiap aspek pada siklus yang dilaksanakan. Nilai rata-rata kemudian dikonversikan berdasarkan kriteria berikut:

Tabel 1. Kriteria Penilaian Keterlaksanan Pembelajaran dan Keterampilan Sosial Siswa

\begin{tabular}{cc}
\hline Kriteria Penilaian & Keterangan \\
\hline $0 \%-20 \%$ & Sangat kurang \\
$21 \%-40 \%$ & Kurang \\
$41 \%-60 \%$ & Cukup \\
$61 \%-80 \%$ & Baik \\
$81 \%-100 \%$ & Sangat baik \\
\hline
\end{tabular}

Keterlaksanaan implementasi Traveller Game Learning berbantuan media Jelajah Nusantara oleh guru saat mengelola pembelajaran dan aktivitas siswa dalam pembelajaran dikatakan efektif apabila memenuhi kriteria baik dan sangat baik. Analisis hasil belajar kognitif siswa dengan mengukur aspek kognitif siawa yaitu dari penilaian hasil belajar peserta didik pada akhir siklus. Jika ketuntasan hasil belajar individu U 75\% maka dianggap tuntas. Ketuntasan klasikal dihitung jika ketuntasan U 80\% maka secara klaksikal dianggap tuntas.

\section{HASIL DAN PEMBAHASAN}

Kondisi awal menunjukkan bahwa hasil belajar kognitif peserta didik pada materi interaksi keruangan dalam kehidupan negara ASEAN sejumlah 30 siswa, siswa yang dinyatakan tuntas hanya 17 siswa sedangkan sisanya 13 siswa dinyatakan tidak tuntas. Hal tersebut dapat diartikan bahwa tingkat ketuntasan siswa hanya 56,67\% dari ketuntasan klasikal 80\%. Nilai rata-rata kelas 68,58 sedangkan nilai KKM mata pelajaran IPS kelas VIII adalah 75. Kondisi tersebut menunjukkan bahwa hasil tes penilaian masih dibawah stándar KKM.

Selain hasil belajar kognitif yang masih dibawah standar KKM, keterampilan sosial siswa kelas VIIIA dalam kegiatan diskusi kelompok juga masih rendah terutama pada kegiatan berbagi tugas dan tanggung jawab. Pada kegiatan ini beberapa siswa dalam kelompok masih bergantung pada siswa yang lain dalam mengerjakan tugas disebabkan dalam satu kelompok ada beberapa teman yang dianggap memiliki kemampuan kognitif lebih baik. Selain itu pada kegiatan kerja sama juga rendah yaitu dalam menyelesaikan tugas kelompok hanya beberapa peserta didik yang mendominasi pengerjaan tugas kelompok dikarenakan memiliki kemampuan kognitif dianggap lebih terampil dibanding beberapa teman dalam kelompoknya.

Siklus I dilaksanakan mulai tanggal 9-16 September 2019. Tahap pertama yang harus dilakukan adalah perencanaan. Pada tahap ini guru mempersiapkan silabus, RPP dengan media Jelajah Nusantara pada materi interaksi keruangan dalam kehidupan di negara ASEAN. Selain itu juga disiapkan lembar instrumen observasi pembelajaran oleh guru, lembar observasi keterampilan sosial siswa, dan instrumen penilaian tes hasil belajar kognitif siswa. Tahap selanjutnya adalah pelaksanaan dengan dua kali pertemuan pembelajaran, serta satu kali pertemuan untuk tes hasil belajar. Setiap pertemuan dilakukan pengamatan dibantu guru pengamat dengan instrumen lembar pengamatan implementasi Traveller Game Learning berbantuan media Jelajah Nusantara oleh guru serta keterampilan sosial peserta didik selama proses pembelajaran.

Berdasarkan data observasi kualitas guru oleh guru pengamat menunjukkan bahwa pada tahap pengumpulan dan pengolahan informasi secara berkelompok terjadi peningkatan. Peningkatan tersebut terjadi pada pertemuan kedua yaitu dari kategori baik meningkat menjadi sangat baik hal ini ditunjukkan dengan guru lebih intensif membimbing siswa pada kegiatan tersebut. Tahap mengembangkan hasil karya juga terjadi peningkatan kualitas pembelajaran pada pertemuan kedua dari ketagori baik menjadi sangat baik. Pada tahap orientasi siswa pada masalah, mengkomunikasikan hasil karya, dan kegiatan penarikan simpulan sudah kategori baik namun perlu ditingkatkan sehingga menjadi sangat baik.

Hasil dari observasi keterampilan sosial siswa di siklus I terjadi peningkatan keterampilan sosial peserta didik pada tiap pertemuannya. Berdasarkan catatan pengamatan, peningkatan tersebut 
terlihat pada kegiatan pembagian tugas serta tanggung jawab, memilih informasi dengan benar, serta kerjasama kelompok semula kategori baik menjadi kategori sangat baik pada pertemuan ketiga. Namun pada kegiatan diskusi pertemuan ketiga terjadi penurunan skor dikarenakan kurangnya menghargai pendapat orang lain pada saat presentasi kelompok. Pada kegiatan ini beberapa siswa dalam beberapa kelompok yang memiliki kemampuan kognitif kategori baik mendominasi kegiatan diskusi dan cenderung memaksakan pendapatnya.

Berdasarkan hasil pelaksanaan tindakan dan pengamatan dari siklus I maka beberapa catatan sebagai refleksi guru untuk perbaikan. Guru perlu memberikan dorongan pada siswa untuk mengajukan pertanyaan terkait dengan suatu permasalahan sosial pada materi yang akan dipelajari. Pada tahap mengembangkan temuan dalam bentuk karya, hendaknya guru lebih aktif lagi berkeliling masing-masing kelompok untuk membimbing siswa dalam mengembangkan karya dalam bentuk peta, data visual matematis contohnya diagram, gambar, dan foto. Pada tahap mengkomunikasikan hasil karya, siswa dengan bimbingan dari guru berlatih dalam teknik komunikasi sehingga siswa mampu mengkomunikasikan hasil karya dengan baik. Indikator keterampilan sosial siswa yang perlu untuk ditingkatkan yaitu berbagi tanggung jawab dan tugas serta memilih informasi yang benar dari berbagai sumber.

Siklus II dilaksanakan mulai tanggal 17-23 September 2019. Tahap pertama yang harus dilakukan adalah perencanaan. Pada tahap ini guru mempersiapkan silabus, RPP dengan media Jelajah Nusantara pada materi interaksi keruangan dalam kehidupan di negara-negara ASEAN. Instrumen lain yang perlu dipersiapkan dipersiapkan yaitu lembar instrumen observasi pembelajaran oleh guru, lembar observasi keterampilan sosial siswa, dan instrumen penilaian tes hasil belajar kognitif siswa. Tahap selanjutnya yaitu pelaksanaan yang dilaksanakan dalam dua pertemuan untuk pembelajaran, dan satu pertemuan untuk diadakan tes hasil belajar. Masing-masing pertemuan dilakukan pengamatan dibantu oleh guru pengamat dengan instrumen lembar pengamatan implemetasi Traveller Game Learning berbantuan media Jelajah Nusantara oleh guru dan keterampilan sosial siswa selama proses pembelajaran.

Pada siklus II ini terdapat peningkatan kualitas pembelajaran dari siklus I. Berdasarkan data observasi kualitas guru menunjukkan bahwa pada tahap pengumpulan dan pengolahan informasi secara berkelompok guru membimbing kelompok yang masih kesulitan pada kegiatan tersebut selain itu juga memberdayakan teman yang lebih terampil sebagai tutor teman sebaya. Tahap mengembangkan hasil karya, hasil karya siswa sudah menunjukkan kemajuan lebih baik sesuai dengan kreatifitas masing-masing kelompok. Pada tahap orientasi siswa pada masalah, mengkomunikasikan hasil karya, dan kegiatan penarikan simpulan siswa dari kelompok berbeda menjukkan keaktifan dengan melakukan tanya jawab dengan kelompok lain untuk memperoleh informasi.

Hasil observasi keterampilan sosial siswa di siklus II terjadi peningkatan keterampilan sosial siswa dari siklus I. Berdasarkan catatan pengamatan, hampir semua aspek pengamatan mengalami peningkatan. Siswa kini dalam kegiatan diskusi kelompok maupun kegiatan pameran hasil karya menunjukkan perilaku menghargai pendapat orang lain. Selain itu pada kegiatan berbagi tugas dan tanggung jawab dalam kelompok, juga mengalami peningkatan dengan siswa aktif dalam kegiatan menghasilkan karya pameran dan tidak menggantungkan temannya. Pada aspek memilih informasi yang benar kini siswa tidak hanya terpaku pada satu sumber belajar untuk menyelesaikan tugas dan karya pameran namun sudah memanfaatakan sumber digital yang dengan cepat membantu mereka menemukan informasi yang dibutuhkan. Untuk aspek kerja sama dalam kelompok menunjukkan peningkatan dengan siswa saling membantu teman yang kesulitan dengan menjadi tutor teman sebaya oleh siswa yang memiliki kompetensi lebih baik membantu temannya yang membutuhkan bantuan.

Berdasarkan hasil pelaksanaan tindakan dan pengamatan dari siklus II maka beberapa catatan sebagai refleksi guru yang harus dilakukan untuk perbaikan yaitu diantaranya dalam pembelajaran guru memberikan dorongan dan melatih secara terus-menerus kemampuan siswa dalam mengajukan pertanyaan terkait dengan suatu permasalahan sosial pada materi yang akan dipelajari. Selain itu pada tahap mengembangkan temuan dalam bentuk karya, guru aktif berkeliling masing-masing kelompok untuk membimbing siswa dalam mengembangkan karya dalam bentuk peta, data visual matematis. Bagi siswa yang belum tuntas diberikan program remedial diluar jam pembelajaran dalam mencapai 
kriteria ketuntasan klasikal dan nilai rata-rata kelas sesuai dengan KKM. Indikator keterampilan sosial siswa yang perlu untuk dilatih terus yaitu yaitu berbagi tugas dan tanggung jawab serta memilih informasi yang benar dari berbagai sumber.

Pada implementasi Traveller Game Learning berbantuan media jelajah Nusantara terdapat peningkatan kualitas pembelajaran IPS oleh guru di kelas VIII A pada materi interaksi keruangan dalam kehidupan di negara-negara ASEAN. Kualitas proses pembelajaran di kelas oleh guru ditunjukkan oleh tabel berikut ini.

Tabel 2 Kualitas proses pembelajaran oleh guru

\begin{tabular}{|c|c|c|c|}
\hline \multirow[t]{2}{*}{ No } & \multirow[t]{2}{*}{ Aspek } & \multicolumn{2}{|c|}{ Siklus } \\
\hline & & I & II \\
\hline 1. & Kegiatan pendahuluan & 5 & 5 \\
\hline \multirow[t]{6}{*}{2.} & Kegiatan Inti & & \\
\hline & a. Orientasi masalah. & 4 & 4 \\
\hline & $\begin{array}{l}\text { b. Pengumpulan dan pengolahan informasi secara } \\
\text { berkelompok }\end{array}$ & 4,5 & 4 \\
\hline & c. Mengembangkan temuan dalam bentuk karya & 4,5 & 5 \\
\hline & d. Mengkomunikasikan karya hasil temuan & 4 & 4 \\
\hline & e. Penarikan simpulan & 4 & 5 \\
\hline \multirow[t]{4}{*}{3} & Kegiatan Penutup & 4 & 5 \\
\hline & Jumlah Skor & 30 & 32 \\
\hline & Persentase & $85,71 \%$ & $91,42 \%$ \\
\hline & Kategori & Sangat Baik & Sangat baik \\
\hline
\end{tabular}

(Sumber: data penelitian 2019)

Berdasarkan tabel 2 di atas menunjukkan terjadi peningkatan kualitas pembelajaran oleh guru di kelas yaitu siklus I 85,71\% menjadi 91,42\% pada siklus II. Hasil penelitian ini memperkuat hasil penelitian sebelumnya dalam penggunaan model dan media pembelajaran yang berdasarkan pada teori belajar konstruktivisme Piaget dan teori belajar Vygotsky yaitu penggunaan model dan media dapat meningkatkan kualitas keterlaksanaan pembelajaran di kelas (Murwantono dan Sukijo, 2015; Pristiwati, 2016; Mu'aini, 2016; Kusrini dan Mustafa, 2019).

Untuk mengetahui kompetensi yang dicapai oleh siswa setelah implementasi Traveller Game Learning berbantuan media Jelajah Nusantara, maka setelah proses pelaksanaan tindakan diperlukan tes hasil belajar. Berikut adalah tes hasil belajar yang dicapai setelah mengikuti pembelajaran di kelas.

Tabel 3. Hasil Belajar Kognitif

\begin{tabular}{clcc}
\hline No & \multicolumn{1}{c}{ Hasil Tes } & Siklus I & Siklus II \\
\hline 1 & Nilai tertinggi & 82,50 & 95 \\
2 & Nilai ternedah & 55 & 67,5 \\
3 & Nilai rata-rata kelas & 73,08 & 82,17 \\
4 & KKM & 75 & 75 \\
5 & Jumlah Siswa & 30 & 30 \\
6 & Jumlah Siswa Tuntas & 23 & 27 \\
7 & Jumlah Siswa Belum tuntas & 7 & 3 \\
8 & Persentase tuntas & $76,67 \%$ & $90 \%$ \\
9 & Persentase tidak tuntas & $23,33 \%$ & $10 \%$ \\
\hline
\end{tabular}

(Sumber: data penelitian 2019)

Berdasarkan tabel 3 di atas menunjukkan terjadi peningkatan hasil belajar kognitif siswa dari siklus I ke siklus || yaitu dengan nilai rata-rata siklus | 73,08 menjadi 82,17 pada siklus II. Selain kenaikan 
nilai rata-rata kelas juga diketahui terjadi kenaikan ketuntasan hasil belajar kognitif siswa dari siklus I 76,67\% menjadi 90\% tuntas pada siklus II. Hasil penelitian ini memperkuat penelitian sebelumnya yang dilakukan oleh Prastini dan Retnowati, 2014; Murwantono dan Sukijo, 2015; Manik dan Gafur, 2016; Suharto dan Zamroni, 2016; Yasri dan Mulyani, 2016 bahwa dalam penggunaan model dan media pembelajaran yang berdasarkan pada teori belajar konstruktivisme Piaget dan teori belajar Vygotsky yaitu penggunaan model dan media dapat meningkatkan hasil belajar siswa.

Selain dilakukan tes hasil belajar kognitif siswa, dalam implementasi Traveller Game Learning berbantuan media Jelajah Nusantara juga dilakukan pengamatan terhadap keterampilan sosial siswa. Data hasil pengamatan oleh pengamat disajikan dalam tabel berikut ini.

Tabel 4. Keterampilan Sosial Siswa Siklus I dan II

\begin{tabular}{lccc}
\hline No & Aspek & Siklus I & Siklus II \\
\hline 1. & Menghargai pendapat orang lain & 4,66 & 5 \\
2. & Berbagi tugas dan tanggung jawab & 3,91 & 4 \\
3. & Memilih informasi yang benar & 3,41 & 4 \\
4. & Kerja sama dalam kelompok & 3,83 & 5 \\
\hline & Skor total & 15,81 & 18 \\
\hline & Persentase & $79,05 \%$ & $90 \%$ \\
\hline & Kategori & Baik & Sangat baik \\
\hline
\end{tabular}

(Sumber: data penelitian 2019).

Berdasarkan tabel 4 diatas menunjukkan hasil pengamatan terhadap keterampilan sosial siswa dalam proses pembelajaran di kelas melalui implentasi Traveller Game Learning berbantuan media Jelajah Nusantara terjadi peningkatan keterampilan sosial siswa siklus I 79,05\% kategori baik meningkat pada siklus II dengan skor 90\% kategori sangat baik. Penggunaan Traveller Game Learning berbantuan media Jelajah Nusantara yang berdasarkan teori belajar Vygotsky menunjukkan bahwa dengan bantuan teman yang terampil dan dibawah bimbingan guru dalam proses scaffolding dapat meningkatkan keterampilan sosial siswa pada tiap pertemuan pembelajaran. Hasil penelitian ini memperkuat penelitian yang dilakukan oleh Amtorunajah dan Masruri, 2015; Suharto dan Zamroni, 2016; Parji dan Andriani, 2016; Lestari dkk, 2019 bahwa dengan bantuan teman yang lebih terampil dan bimbingan guru dalam proses scaffolding dapat meningkatkan keterampilan sosial siswa.

\section{SIMPULAN DAN SARAN}

Implementasi Traveller Game Learning berbantuan media Jelajah Nusantara mengikuti prosedur penelitian tindakan kelas dengan bentuk siklus berulang yang terdapat empat tahap utama kegiatan, yaitu (a) perencanaan; (b) tindakan; (c) pengamatan; dan (d) refleksi. Pelaksanaan tindakan dilakukan dalam dua siklus. Terdapat peningkatan kualitas pembelajaran oleh guru di kelas yaitu siklus I semula 85,71\% menjadi $91,42 \%$ pada siklus II. Sedangkan hasil belajar kognitif siswa setelah tindakan terjadi peningkatan yaitu siklus I dengan rerata awal 73,08 menjadi 82,17 di siklus II. Selain itu terjadi pula peningkatan nilai rata-rata kelas pada ketuntasan klasikal yaitu dari semula $76,67 \%$ pada siklus I menjadi $90 \%$ di siklus II. Untuk keterampilan sosial siswa terdapat peningkatan kualitas yaitu semula 79,05\% kategori baik di siklus I menjadi 90\% pada siklus II pada kategori sangat baik.

Implementasi Traveller Game Learning berbantuan media Jelajah Nusantara pada mata pelajaran IPS di kelas VIII A terbukti mampu meningkatkan kualitas pembelajaran. Peningkatan tersebut meliputi peningkatan kualitas oleh guru di kelas, hasil belajar kognitif, dan keterampilan sosial siswa. Berdasarkan hasil impelentasi pembelajaran dapat diketahui bahwa penggunaan kombinasi model dan media pembelajaran ini bisa dimanfaatkan sebagai alternatif proses pembelajaran di kelas. Selanjutnya model dan media pembelajaran ini dapat dikembangkan lagi, baik oleh guru, satuan pendidikan, maupun lembaga pengembang pendidikan lainnya dengan harapan ke depan menjadi lebih baik. 


\section{PUSTAKA ACUAN}

Akbar, S. Instrumen Perangkat Pembelajaran. Bandung: PT. Remaja Rosdakarya, 2013.

Amtorunajah dan Masruri. "Peningkatan Keterampilan Sosial Siswa dalam Pembelajaran IPS Melalui Outdoor Activity di SMP Negeri 1 Kaligondang Kabupaten Purbalingga." Jurnal Harmoni Sosial 2, no.5 (2015):1-11.

Hopkins, D. Panduan Guru Penelitian Tindakan Kelas-A Teacher's Guide To Classroom Research.Yogjakarta: Pustaka Pelajar, 2011.

Kusrini, dan Mustofa, F. Penerapan Model Problem Based Learning (PBL) dalam Meningkatkan Hasil Belajar IPS Geografi Siswa Kelas VIII MTs Ar-Ridha Paisumbaos Halmahera-Selatan. Jurnal Geocivic 2, no.2 (2019):229-234.

Lestari, E.F., Zainuddin, M., Soetjipto, B.E. “Peningkatan Keterampilan Sosial dan Hasil Belajar menggunakan Model Pembelajaran Kooperatif Roundtable dan Carousel Feedback". Jurnal Pendidikan: Teori, Penelitian, dan Pengembangan 4, no.10 (2019):1304-1308.

Mu'aini. Peningkatan Kualitas Pembelajaran IPS Melalui Penerapan Metode Problem Based Learning Di SMP Negeri 15 Kota Yogyakarta. Jurnal Pendidikan IImu Pengetahuan Sosial Indonesia 1, no.3 (2016):45-62.

Manik, K dan Gafur, A. "Penerapan Model Two Stay Two Stray Berbantuan Multimedia Untuk Meningkatkan Aktivitas dan Hasil Belajar IPS". Jurnal Harmoni Sosial: Jurnal Pendidikan IPS 3, no.1(2016):39-49.

Murwantono \& Sukijo. "Peningkatan Hasil Belajar IPS Dengan Model Problem Based Learning Berbantuan Media Stimulan Gambar". Jurnal Harmoni Sosial: Jurnal Pendidikan IPS 2, no.1 (2015):30-41.

Parji dan Andriani, R.E. "Upaya Peningkatan Keterampilan Sosial Siswa Melalui Permainan Tradisional Congklak". Gulawentah: Jurnal Studi Sosial 1, no.1 (2016):14-23.

Prastini dan Retnowati. "Peningkatan Keterampilan Sosial dan Hasil Belajar IPS Melalui Model Kooperatif TGT Di SMPN 1 Secang." Jurnal Harmoni Sosial 1, no.2 (2014):165-178

Pristiwati. "Penerapan Model Pembelajaran Inquiry untuk Meningkatan Hasil Belajar PKn tentang Kebebasan Berorganisasi." Jurnal Ilmu Pendidikan 1, no.2 (2016):40-46.

Schunk, D.H. Teori-Teori Pembelajaran-Perspektif Pendidikan Edisi keenam. Yogjakarta: Pustaka Pelajar, 2012.

Suharto dan Zamroni. "Peningkatan Hasil Dan Aktivitas Belajar IPS Model Problem-Based Learning Berbantuan Media SMPN 2 Kawunganten". Jurnal Harmoni Sosial: Jurnal Pendidikan IPS 3, no.1 (2016):82-94.

Suparno, P. Filsafat Konstruktivisme dalam Pendidikan. Yogjakarta: Kanisius, 2014

Yasri, H.L., \& Mulyani, E. "Efektivitas Penggunaan Media Film Untuk Meningkatkan Minat dan Hasil Belajar Ekonomi Siswa Kelas X". Jurnal Harmoni Sosial: Jurnal Pendidikan IPS 3, no.1 (2016):138-149. 